\title{
Career Counselling at the Middle School Level: A Case Study
}

\section{Harry L. Legum}

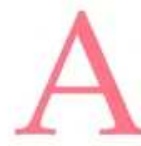

mong the national stand ards stressed by The American School Counselor Association (1997) is the academic and career development among all students. In other words, it is essential that students understand the connection between academics to the world of work. Although 18 percent of Canada's high school students drop out of school (Canadian Centre for Adolescent Research, 2000), current data indicate that 9.4 percent of American high school students drop out of school (United States Department of Commerce, 2003). Since the unemployment rate of high school dropouts in Canada is 55 percent (Little, 2003) and 18 percent in the United States (United States Department of Commerce), it is necessary for students, especially at the middle school level, to understand the relevance of learning to their future career choice. These high school dropouts are confronted with barriers preventing them from succeeding in the world of work. Thus, at-risk students must develop skills that will adequately prepare them for career options and make them more desirable to future employers (Legum \& Hoare, 2004).

The second goal of Baltimore County's school-based guidance and counselling program states that students should "develop career awareness and decisionmaking competencies." Baltimore County Public School's guidance program emphasizes career awareness and career exploration for all students beginning in elementary school and continuing through high school (Baltimore County Board of Education, Department of Student Services, 1996). At the middle school level, career awareness is stressed; however, students begin a more in-depth exploration.

There is evidence suggesting a positive correlation between middle (Kelly, 1992; Kelly \& Cobb, 1991; Kelly \& Colangelo, 1990) and high school students' (Mau, 2003; Mullis, Mullis, \& Brailsford, 1997, Westbrook, Sanford, Merwin, Fleenor, \& Gilleland, 1988) career maturity levels and their academic achievement. Given that career choice is among the developmental tasks of adolescence (Erikson, 1968; Young, 1994), the review of literature indicates that implementing career interventions at the middle school level is an important factor that helps to increase at-risk students' self-esteem (D'Andrea \& Daniels, 1992; Legum \& Hoare, 2004; Medina \& Drummond, 1993; Robitschek, 1996; Wood, Hillman, \& Sanilowsky, 1996) and academic achievement (Legum \& Hoare). Therefore, exploring career options, especially at the middle school level, is a vital constituent helping to increase students' resiliency, self-confidence in their ability to succeed, and better preparing them for future career selections.

Do professional middle school counsellors perceive career counselling as an integral part of their daily functions? Among the duties a middle school counsellor partakes in are individual counselling, group counselling, classroom guidance, career development initiatives, ARD (Admission, Review, and Dismissal) meetings, teacher team meetings, and staff development, to enumerate a few. The researcher conducted a case study with a professional middle school counsellor to investigate the importance of career counselling at the middle school level.

\section{Methodology}

The researcher purposively chose one professional middle school counsellor from the Baltimore County Public School System whom he knew and regarded as a professional colleague. The middle school is located in the southwest area of Baltimore County and has a student body of 800 pupils comprising sixth-, seventh, and eighth-graders. Ninety-five percent of the students are Caucasian with middle class income/ occupational status.

\section{Materials}

The professional middle school counsellor kept a daily diary for three days which detailed the counselling/miscellaneous activities she conducted. This provided the basis for our 30-minute semi-structured interview. The professional middle school counsellor was made aware at the beginning of the interview that the purpose of this study was to investigate the importance of ca- 


\section{2:3 Fall 2005}

reer counselling at the middle school level. Although the outset of the interview was semi-structured since it contained a set of pre-determined open-ended questions, the researcher asked additional questions based on the interviewee's responses for further insight. For example, the interview included questions such as:

a. As a professional middle school counsellor, what is your typical day like?

b. How much time is allocated to each of the counselling activities you just mentioned?

c. What types of career counselling activities do you employ?

d. How important do you think career counselling is at the middle school level?

e. How do you see career counselling impacting middle school students both in the short and long-term future?

\section{Data Analysis}

The interview was audio-taped and transcribed. Subsequently, the researcher coded the data. Coding involves systemizing data into categories linked to the research questions so that they can be used to support analysis and interpretation (LeCompte \& Schensul, 1999). The first stage of coding in this study was the identification of the themes culminating from the raw data collected during the interview. The following represent an exemplification:

a. Career counselling activities;

b. Importance of career counselling at the middle school level;

c. Percentage of the day a middle school counsellor allocates to the delivery of various guidance services to middle school students.

The second stage of analysis was an examination of the categories identified to determine how they were interrelated.

\section{Results}

As a result of the data collected from the interview of the professional middle school counsellor, the following represent fundamental themes:

a. A typical professional middle school counsellor's daily activities will vary depending on the demands of administrators, teachers, and staff for a particular day.

b. Teacher team meetings, pupil services ARD conferences, individual counselling related to conflict resolution and school achievement, individual counselling as it pertains to planning for a high school program concentration, group counselling, parent consultation, and career counselling represent typical school counselling activities. Nonetheless, approximately 70 percent of the day is career oriented; 20 percent is centred around individual counselling (student achievement and conflict resolution); while 10 percent focuses on pupil services ARD conferences, group work, or unexpected paper work.

c. Career counselling strategies include visiting different work sites or job shadowing, conducting a career fair at the school site where different guest speakers would address various student career interests, and leading classroom guidance lessons with the notion that students will complete an interest inventory. As a result, students will identify their strengths and goals, and accordingly, learn the level of education required to accommodate their aspirations.

d. Career counselling is very important in middle school because it helps students develop a direction for their short and long-term future. In the short-term, students begin to think about their areas of interest resulting in a selection of high school courses best serving their needs. In the long-term, students will develop those attitudes and work habits to enable them to be successful in later life. The interviewee stated, "... to be lifelong learners so that they can change as the world of work changes."

\section{Limitations}

This study is restricted by the following shortcomings:

a. No data were collected from middle school counsellors in other school counties within the state of Maryland. The sample was comprised of one Baltimore County professional middle school counsellor. Therefore, the conclusions are based on a finite collection of data.

b. There was little attempt to specifically determine how the following variables may have impacted the middle school counsellor's perceptions toward career counselling at this level:

- Special education students;

- Ethnicity of students;

- Gender of student.

\section{Conclusions/}

\section{Recommendations}

Career guidance can be viewed as a delivery system which strategically assists students obtain the career development outcomes of self-awareness and assessment, career awareness and exploration, career decision-making, career planning and placement (American School Counselor Association, 1984). This research study addressed the issue of career counselling at the middle school level. In accordance with the data collected from the professional middle school counselor, the researcher concludes with the following thoughts:

a. Although career counselling is a stated goal for middle school counsellors (American School Counselor Association, 1997), the amount of affordable time will vary depending on the demands of the particular middle school administration and staff. 
b. At the middle school level, exposure to pertinent career activities will provide students with the appropriate groundwork for subsequent career planning and decision-making.

c. Career development is a lifelong process. At the middle school level, an adolescent should keep all of his/her options open, and not become fully committed to a particular field. Since the world of work is constantly changing, it is important that a middle school youngster adapts the mindset of a lifelong learner.

d. Students need to be motivated in the school setting to obtain the knowledge and skills necessary to succeed in the world of work (Rhoder and French, 1999). One plausible approach that can be used in the classroom is called, "contextual teaching and learning". It is a theoretical framework in which teachers present their pupils with academic course material in such in a way that motivates these students to learn because such students begin to recognize the connection between what is learned in the classroom is applicable in many occupations (Hoyt, 2001). Hoyt said:

"If teachers are to be motivated to use a career education approach to teaching, they must be convinced that, if they do so, pupils will learn more, and teachers will receive some of the credit. If pupils are to be more motivated to learn through the use of a career education approach, their 'Why should I learn this?' questions must be answered, in part, by helping them see how what is being taught is used by workers in a variety of occupations (p. 328)."

It is also important for teachers to provide school to work examples within the students' experiences and understanding (Evans, Hoyt, \& Mangum, 1973). In order to accommodate this feat, teachers should take an in-service training to enable them to be better prepared and equip to provide such services to all students, especially at the elementary and middle school levels.

e. The following websites are recommended to enable students to acquire information about the education and training needed for various occupations:

\section{www.acinet.org}

www.bls.gov/oco

\section{www.online.onetcenter.org}

www.rileyguide.com (for jobseeking skills, resume writing, and job interviewing).

The following are recommendations for future studies related to career counselling at the middle school level:

a. The sample should include randomly selected middle school counsellors from different areas within a geographic region.

b. Rather than limit data collection techniques to journaling and interviewing, the addition of observations, surveys, or questionnaires would help to strengthen any potential study.

c. Future studies should be performed to determine how special education middle school students as well as the ethnicity and gender of middle school students are affected by the implementation of career counselling at this level.

Given the need for middle school students to make high school course selections, a clear idea of a career at this juncture is highly improbable. Therefore, students' short and long-range goal setting regarding interests and culminating in career exploration is advisable. Career counselling at the middle school level is of paramount importance ultimately contributing to the students' immediate and lasting success.

\section{References}

American School Counselor Association. (1997). The national standards for school counseling programs. Alexandria, VA: Author. Retrieved January 10, 2004, from http://ww.schoolcounselor.org.

American School Counselor Association. (1984). The school counselor in career guidance: Expectations and responsibilities. Alexandria, VA: Author.

Baltimore County Board of Education, Department of Student Services, Office of Guidance and Counseling. (1996). Baltimore County Public Schools essential guidance program preK-12. Baltimore: Board of Education of Baltimore County.

Canadian Centre for Adolescent Research. (2000). Canadian centre for adolescent research: High school dropouts. Canada: Author.

D'Andrea, M., \& Daniels, J. (1992). A career development program for inner city black youth. The Career Development Quarterly, 40(3), 272-280.

Erikson, E.H. (1968). Identity: Youth and crisis. New York: Norton.

Evans, R., Hoyt, K.B., \& Mangum, G. (1973). Career education in the middle/ junior high school. Utah: Olympus Publishing Company.

Hoyt, K.B. (2001). Career education and education reform: Time for a rebirth. Phi Delta Kappan, 83(4), 327-331.

Kelly, K. (1992). Career maturity of young gifted adolescents: A replication study. Journal for the Education of the Gifted, 16(1), 36-45.

Kelly, K.R., \& Cobb, S. (1991). A profile of the career development characteristics of young gifted adolescents: Examining gender and multicultural differences. Roeper Review, 13, 202-206.

Kelly, K.R., \& Colangelo, N. (1990). Effects of academic ability and gender on career development. Journal for the Education of the Gifted, 13(2), 168-175.

LeCompte, M.D., \& Schedsul, J.J. (1999). Analyzing and interpreting ethnographic data. WalnutCreek, CA: AltaMira Press.

Legum, H.L., \& Hoare, C.H. (2004). Impact of a career intervention on atrisk middle School students' career maturity levels, academic achievement, and self-esteem. Professional School Counseling, 8(2), 148-155.

Little, B. (2003). Jobs decline for best and least educated. Retrieved July 16, 2005, from http://www.jobsvolution.ca/ article.cfm 
2:3 Fall 2005

Mau, W-C. (2003). Factors that influence persistence in science and engineering career aspirations. Career Development Quarterly, 51, 234-243.

Medina, V., \& Drummond, R.J. (1993). Profile of rural college reach-out students. Journal of Employment Counseling, $30,15-24$.

Mullis, A.K., Mullis, R.L., \& Brailsford, J.C. (1997). Relationships between academic comfort and career interests among rural high school students. Psychological Reports, 80, 459-466.

Rhoder, C., \& French, J.N . (1999). Schoolto-work: Making specific connections. Phi Delta Kappan, 80(7), 534-542.

Robitschek, C. (1996). At-risk youth and hope: Incorporating a ropes course into a summer jobs program. The Career Development Quarterly, 45, 163-169.

United States Department of Commerce, (2003). Statistical abstract of the United
States: 2003 (123 $3^{\text {rd }}$ ed.). Washington, DC: Author.

Westbrook, B.W., Sanford, E.E., Merwin, G., Fleenor, J., \& Gilleland, K. (1988). Career maturity in grade 9: Can students who make appropriate career choices for others also make appropriate career choices for themselves. Measurement and Evaluation in Counseling and Development, 21, 64-71.

Wood, P.C., Hillman, S.B., \& Sanilowsky, S.S. (1996). Locus of control, self-concept, and self-esteem among at-risk African-American adolescents. Adolescence, 31(23), 597-604.

Young, R.A. (1994). Helping adolescents with career development: The active role of parents. The Career Development Quarterly, 42, 195-204.

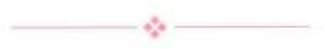

\& LEARNING

Dr. Harry L. Legum received his Ph.D. in Counseling from The George Washington University. In addition to

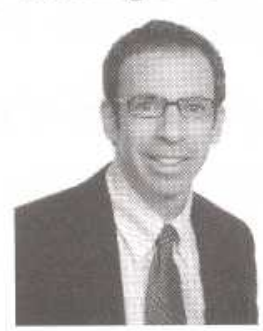
being to a National Certified and Licensed Clini-cal Professiona 1 Counselor and an assistant professor at Coppin State University, he has presented at national and regional conferences and has published on school related topics. Dr. Legum is a member of the editorial board of the Journal of Counseling and Development, and is a long standing member of the American Counseling Association, Maryland Association of Counseling and Development, and the American School Counselors Association."

\section{Quotations: Ray Chodzinski}

A favourite warm up activity I used with pre service and graduate students was to begin a discussion with a quote by an individual who influenced my teaching. Here are few.

\section{Carl Rogers}

If we value independence, if we are disturbed by the growing conformity of knowledge, of values, of attitudes, which our present system induces, then we may wish to set up conditions of learning which make for uniqueness, for self-direction, and for self-initiated learning.

\section{Fritz Redl}

Boredom will always remain the greatest enemy of school disciplines. If we remember that children are bored, not only when they do not happen to be interested in the subject or when the teacher does not make it interesting, but also when certain working conditions are out of focus with their basic needs, then we can realize what a great contributor to discipline problems boredom really is. Research has shown that boredom is closely related to frustration and that the effect of too much frustration is invariably irritability, withdrawal, rebellious opposition or aggressive rejection of the whole show.

\section{Paulo Freire}

Education either functions as an instrument which is used to facilitate integration of the younger generation into the logic of the present system and bring about conformity or it becomes the practice of freedom, the means by which men and women deal critically with reality and discover how to participate in the transformation of their world.

\section{Albert Einstein}

It is, in fact, nothing short of a miracle that the modern methods of instruction have not entirely strangled the holy curiosity of inquiry.

\section{Alvin Toffler}

The illiterate of the $21^{\text {st }}$ century will not be those who cannot read and write, but those who cannot learn, unlearn, and relearn.

\section{William Butler Yeats}

Education is not the filling of the pail, but the lighting of a fire. 